\title{
COMPARISON OF BASIC INTERNAL AND EXTERNAL EGG QUALITY TRAITS OF BROWN AND WHITE EGG-LAYING HENS IN RELATIONSHIP TO THEIR AGE
}

\author{
Adam Kraus ${ }^{1}$, Lukáš Zita ${ }^{1}$, Ondřej Krunt ${ }^{1}$, Zdeněk Volek², \\ Milan Tyller ${ }^{3}$ Vojtěch Anderle 3
}

\footnotetext{
${ }^{1}$ Department of Animal Science, Faculty of Agrobiology, Food and Natural Resources, Czech University of Life Sciences Prague, Kamýcká 129, 16500 Prague, Czech Republic

${ }^{2}$ Department of Microbiology, Nutrition and Dietetics, Faculty of Agrobiology, Food and Natural Resources, Czech University of Life Sciences Prague, Kamýcká 129, 16500 Prague, Czech Republic

${ }^{3}$ DOMINANT CZ, Voleč 119, 53341 Lázně Bohdaneč, Czech Republic
}

Link to this article: https://doi.org/10.11118/actaun202068010049

Received: 12. 8. 2019, Accepted: 5. 12. 2019

To cite this article: KRAUS ADAM, ZITA LUKÁŠ, KRUNT ONDŘEJ, VOLEK ZDENĚK, TYLLER MILAN, ANDERLE VOJTĚCH. 2020. Comparison of Basic Internal and External Egg Quality Traits of Brown and White Egg-laying Hens in Relationship to their Age. Acta Universitatis Agriculturae et Silviculturae Mendelianae Brunensis, 68(1): 49-56.

\begin{abstract}
This study was focused on the comparison of the brown and white eggs from two laying hybrids. The objective was to assess basic quality traits of eggs from both groups of hens and compare them. The impact of how age influences the technological value of eggs was also observed. The most important correlations were calculated. Products of Czech original genetic programmes, Dominant Brown D 102 and Dominant Leghorn D 229 hens were included. A total of 1500 eggs were analysed. The egg collection was made for three consecutive days when the hens were at the 28, 35 and 59 weeks of age. The results showed that eggshell weight, yolk weight and yolk share increased with the age, while egg shape index, yolk index and albumen share decreased in both hybrids. Eggshell weight and share fluctuated with the age in both hybrids. Other traits differed within the hybrids. Interactions between age and hybrid were non-significant ( $\mathrm{P}>0.05$ ) only in eggshell and yolk weight. The heaviest eggs were from 59-week-old Dominant Brown D 102 hens $(68.89 \mathrm{~g})$ and the lightest eggs were from 28-week-old Dominant Leghorn D 229 hens (57.76 g). Highly significant ( $\leq 0.001$ ) positive correlations were found between egg weight and all individual egg components weights and between eggshell weight and yolk and albumen weight and eggshell thickness in both laying hybrids.
\end{abstract}

Keywords: age, albumen, Dominant Brown D 102, Dominant Leghorn D 229, egg, egg quality, eggshell, genotype, yolk

\section{INTRODUCTION}

The preferences and requirements of the consumers regarding food differ nowadays from country to country and eggs are not an exception (Aygun, 2014). Besides other important aspects such as egg weight or eggshell integrity, one of the main aspects that have an influence on the customers' choice is eggshell colour (Arthur and O'Sullivan, 2005). Nevertheless, eggshell colour does not determine internal quality of eggs (Odabaşi et al., 2007; Samiullah et al., 2015). The hens could be divided into two basic groups depending on the eggs they lay, first group lay eggs with brown 
eggshell and the other eggs with white eggshell (Arthur and O'Sullivan, 2005). Furthermore, some breeds lay eggs with different eggshell colour, which may vary from creamy, to green and blue to dark brown (Samiullah et al., 2015). Generally, in Africa, Australia and Europe, the vast majority of eggs on the market are brown. However, in both, Latin and North America and in Asia the trend is the opposite. When considering worldwide production, ratio between eggs with brown eggshell colour and eggs with white eggshell colour is roughly balanced (Hooge, 2007; Windhorst et al., 2013). Eggshell colour is substantially influenced by genotype (Arthur and O'Sullivan, 2005). According to Kraus and Zita (2019), genotype and age are among the most important factors that have an effect not only on the eggshell colour, but also on the other egg quality traits. Many other authors including Campo et al. (2007), Anderson (2013) or Zita et al. (2018) confirm significant effect of genotype on egg quality. There are notable genetic differences between brown and white egg-laying hens that mainly relate to body constitution, laying performance and some traits of egg quality. However, these differences constantly decrease thanks to intensive breeding programs (Ledvinka et al., 2012). From the consumers' point of view, another important aspect is the occurrence of blood and meat spots in yolk and/or in albumen, which lower in eggs from white egg layers (Arthur and O'Sullivan, 2005). The effect of age on the basic quality traits is obvious from various studies including Zita et al. (2009), Hanusová et al. (2015) and Lee et al. (2016).

This study was focused on the comparison of the eggs from the two most used groups of layers in the world, brown and white egg-laying hens, specifically on products of Czech original genetic programmes, Dominant Brown D 102 and Dominant Leghorn D 229. The objective was to assess basic quality traits of eggs from both groups of hens and compare them. The impact of how age influences the technological value of eggs was also observed. Interactions between age and hybrid were determined. Last but not least, the most important correlations among the egg quality traits were calculated.

\section{MATERIALS AND METHODS}

\section{Animals and Housing Conditions}

Dominant Brown D 102 and Dominant Leghorn D 229 hens were included in this experiment. Both hybrids came from the company Dominant CZ. Dominant Brown D 102 hens are the result of crossing Rhode Island White at maternal stock and Rhode Island Red at paternal stock. Dominant Leghorn D 229 hens are the result of crossing White Leghorns in maternal and paternal stock (Tyller, 2015). According to the data from the International Poultry Testing, Ústrašice, Czech Republic hen-day egg production of Dominant Brown D 102 hens is 320 pcs and the average weight of eggs is $64.3 \mathrm{~g}$ (Klejnová and Koželuhová, 2014). Hen-day egg production of Dominant Leghorn D 229 hens is 333 pcs and the average weight of eggs is $60.5 \mathrm{~g}$ (Klejnová and Koželuhová, 2012). Laying period in both hybrids lasted until the 74 weeks of age.

All hens were randomly placed in enriched cages that meet the requirements specified by Directive 1999/74/EC, which sets minimum standards for protection of layers. The cages were equipped with nipple drinkers and trough feeders. Hens were fed by a commercial type of feed mixture containing $11.50 \mathrm{MJ}$ of metabolizable energy and 16.64\% of crude protein from the age of 20 weeks. In the following period, from the age of 41 weeks, there was used feed mixture that contained $11.09 \mathrm{MJ}$ of metabolizable energy and $15.02 \%$ of crude protein. Both feed and water were supplied ad libitum. The lighting regime was set to $16 \mathrm{~h}$ of light and $8 \mathrm{~h}$ of darkness. The lighting intensity values acquired from 5 to $10 \mathrm{~lx}$. The conditions of microclimate were kept on the same level during the whole observation that took place at the Demonstration and Experimental Center of the Faculty of Agrobiology, Food and Natural Resources.

\section{Laboratory Evaluation}

A total of 1500 eggs were analysed during the laboratory evaluation and all basic measurements were performed on each one of them. The egg collection was made for three consecutive days when the hens were at the 28, 35 and 59 weeks of age. The storage of eggs was realized under controlled conditions, where the constant temperature of $6{ }^{\circ} \mathrm{C}$ was preserved. The laboratory analysis took place 24 hours after the collection. The evaluation of technological value of eggs was realized according to Kraus and Zita (2019).

\section{Statistical Evaluation of the Results}

All data of egg quality traits were processed by the computer program SAS (SAS Inst. Inc., 2011). The results of the particular traits of egg quality were assessed by the mixed model by PROC MIXED:

$y_{i j k}=\mu+A_{i}+H_{j}+A H_{i j}+e_{i j k}$,

where $y_{i j k}$ was the value of the sign, $A_{i}$ was the effect of age (28, 35 and 59 weeks of age), $H_{\text {. was }}$ the effect of hybrid (Dominant Brown D 102 or Dominant Leghorn D 229), $A H_{i j}$ was the effect of interaction between age and hybrid, $e_{i j k}$ was the random residual error. Scheffe's multiple range test was performed when the P-values were significant $(\mathrm{P} \leq 0.05)$. All the data are showed as means with standard errors. Pearson's correlation coefficients were calculated among some egg quality traits in PROC CORR (SAS Inst. Inc., 2011). Correlations were considered significant when the associated P-value was less than 0.05 . 


\section{RESULTS}

The findings of this study are described in Tabs. I-III and Fig. 1. Basic quality traits of the whole egg and its external part are shown in the Tab. I, while traits of internal parts in Tab. II. The most important correlations among the chosen traits are shown in Tab. III. The share of individual egg parts is described in Fig. 1.

The egg weight (Tab. I) was significantly $(\mathrm{P}=0.011)$ influenced by interaction between age and hybrid. The heaviest eggs were from 59-week-old Dominant Brown D 102 hens (68.89 g). Vice versa, the lightest eggs were from 28-week-old Dominant Leghorn D 229 hens (57.76 g). The eggs from 28-week-old Dominant Brown D 102 hens had significantly $(\mathrm{P}=0.017)$ the highest value of egg shape index (77.98\%) contrary to eggs of this genotype analysed at the age of 59 weeks (75.68\%) and eggs from Dominant Leghorn D 229 hens (75.49, 75.27 and 75.09\%).

There was not found the interaction $(\mathrm{P}=0.956)$ between age and hybrid in eggshell weight (Tab. I). The heaviest eggshell was detected in eggs from 35-week-old Dominant Brown D 102 and Leghorn D 229 hens (6.07 g), whereas the lightest eggshell was observed in eggs from 28-week-old Dominant Brown D 102 hens (5.50 g) and Dominant Leghorn D 229 hens (5.51 g). The eggshell share (Fig. 1) was significantly $(\mathrm{P}=0.042)$ influenced by interaction between age and hybrid. The highest eggshell share was found in eggs from 35-week-old Dominant Leghorn D 229 hens (10.19\%), while the lowest eggshell share was found in eggs from 59-week-old Dominant Brown D 102 hens (8.61\%). There was detected significant interaction $(\mathrm{P}=0.032)$ between age and hybrid in eggshell thickness (Tab. I). The thickest eggshell had eggs from Dominant Leghorn D 229 hens (0.354, 0.349 and $0.346 \mathrm{~mm})$ contrary to eggs from 28-week-old (0.324 mm) and 59-week-old (0.326 mm) Dominant Brown D 102 hens. Eggshell strength was significantly $(\mathrm{P}=0.001)$ influenced by interaction between age and hybrid. The eggs with the highest eggshell strength came from 28-week-old Dominant Leghorn D 229 hens $\left(44.13 \mathrm{~N} / \mathrm{cm}^{2}\right)$, while eggs with the lowest eggshell strength came from 28 and 59-week-old Dominant Brown D 102 hens (34.73 and $35.04 \mathrm{~N} / \mathrm{cm}^{2}$ ). The eggshell colour was observed for determination of correlations. Statistically significant $(P=0.001)$ effect of interaction between age and hybrid was detected in eggshell colour. The eggs with the lightest colour were from 59-week-old Dominant Leghorn D 229 hens (83.63\%) contrary to eggs from 28 and 35-week-old Dominant Brown D 102 hens (39.92 and 38.67\%).

I: Basic quality traits of the whole egg and its external part in relationship to hybrid and age (mean $\pm S E$ )

\begin{tabular}{|c|c|c|c|c|c|c|c|}
\hline \multirow[b]{2}{*}{ Trait } & \multirow{2}{*}{$\begin{array}{c}\text { Age } \\
\text { (weeks) }\end{array}$} & \multicolumn{2}{|c|}{ Hybrid } & \multicolumn{3}{|c|}{ Significance } & \multirow[b]{2}{*}{ SEM } \\
\hline & & $\begin{array}{l}\text { Dominant } \\
\text { D } 102\end{array}$ & $\begin{array}{l}\text { Dominant } \\
\text { D } 229\end{array}$ & Age & Hybrid & Age $\times$ Hybrid & \\
\hline \multirow{3}{*}{ Egg weight (g) } & 28 & $60.81^{\mathrm{d}} \pm 0.42$ & $57.76^{e} \pm 0.59$ & \multirow{3}{*}{0.001} & \multirow{3}{*}{0.001} & \multirow{3}{*}{0.011} & \multirow{3}{*}{0.249} \\
\hline & 35 & $64.47^{b} \pm 0.42$ & $59.60^{d} \pm 0.52$ & & & & \\
\hline & 59 & $68.89^{\mathrm{a}} \pm 0.44$ & $62.75^{c} \pm 0.60$ & & & & \\
\hline \multirow{3}{*}{ Egg shape index (\%) } & 28 & $77.98^{\mathrm{a}} \pm 0.27$ & $75.49^{c} \pm 0.39$ & \multirow{3}{*}{0.001} & \multirow{3}{*}{0.001} & \multirow{3}{*}{0.017} & \multirow{3}{*}{0.137} \\
\hline & 35 & $77.18^{b} \pm 0.27$ & $75.27^{c} \pm 0.34$ & & & & \\
\hline & 59 & $75.68^{c} \pm 0.29$ & $75.09^{c} \pm 0.39$ & & & & \\
\hline \multirow{3}{*}{ Eggshell weight (g) } & 28 & $5.50 \pm 0.05$ & $5.51 \pm 0.07$ & \multirow{3}{*}{0.001} & \multirow{3}{*}{0.726} & \multirow{3}{*}{0.956} & \multirow{3}{*}{0.025} \\
\hline & 35 & $6.07 \pm 0.05$ & $6.07 \pm 0.06$ & & & & \\
\hline & 59 & $5.93 \pm 0.05$ & $5.97 \pm 0.07$ & & & & \\
\hline \multirow{3}{*}{ Eggshell thickness (mm) } & 28 & $0.324^{c} \pm 0.002$ & $0.354^{a} \pm 0.003$ & \multirow{3}{*}{0.117} & \multirow{3}{*}{0.001} & \multirow{3}{*}{0.032} & \multirow{3}{*}{0.001} \\
\hline & 35 & $0.334^{b} \pm 0.002$ & $0.349^{a} \pm 0.003$ & & & & \\
\hline & 59 & $0.326^{c} \pm 0.003$ & $0.346^{a} \pm 0.003$ & & & & \\
\hline \multirow{3}{*}{ Eggshell strength $\left(\mathrm{N} / \mathrm{cm}^{2}\right)$} & 28 & $34.73^{\mathrm{d}} \pm 0.70$ & $44.13^{\mathrm{a}} \pm 0.99$ & \multirow{3}{*}{0.002} & \multirow{3}{*}{0.001} & \multirow{3}{*}{0.001} & \multirow{3}{*}{0.356} \\
\hline & 35 & $38.54^{\mathrm{c}} \pm 0.70$ & $41.86^{\mathrm{ab}} \pm 0.87$ & & & & \\
\hline & 59 & $35.04^{\mathrm{d}} \pm 0.74$ & $39.53^{\mathrm{bc}} \pm 1.00$ & & & & \\
\hline \multirow{3}{*}{ Eggshell colour (\%) } & 28 & $39.92^{d} \pm 0.46$ & $71.79^{b} \pm 0.65$ & \multirow{3}{*}{0.001} & \multirow{3}{*}{0.001} & \multirow{3}{*}{0.001} & \multirow{3}{*}{0.762} \\
\hline & 35 & $38.67^{d} \pm 0.46$ & $71.80^{b} \pm 0.57$ & & & & \\
\hline & 59 & $44.04^{c} \pm 0.49$ & $83.63^{a} \pm 0.66$ & & & & \\
\hline
\end{tabular}

Data labelled with same superscript letters in concrete trait do not differ significantly (abcdeP $\leq$ 0.05); SE - Standard Error; Dominant D 102 - brown egg-layers; Dominant D 229 - white egg-layers; SEM - Standard Error of the Mean 


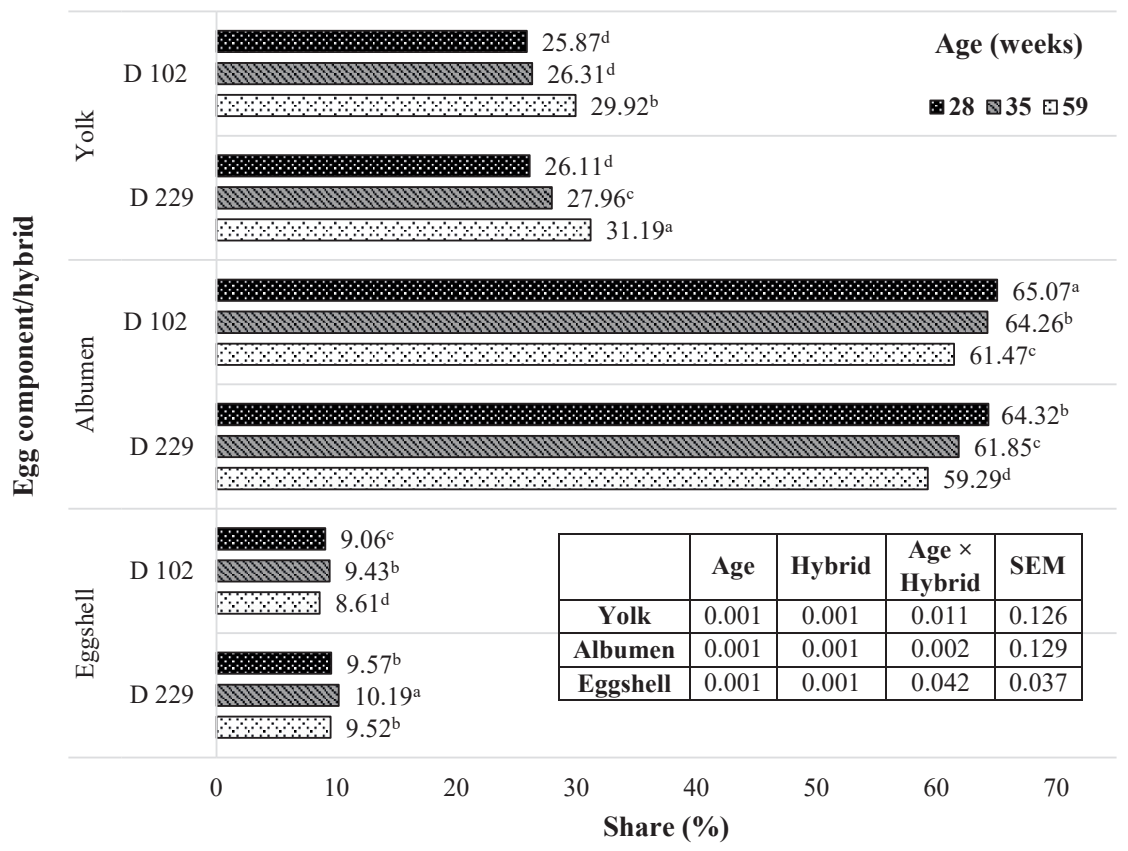

1: Share of individual egg components in relationship to hybrid and age of hens

Data labelled with same superscript letters in concrete trait do not differ significantly

( $^{\text {abcd }}$ P 0.05); D 102 - brown egg-layers Dominant; D 229 - white egg-layers Dominant

II: Basic quality traits of internal parts of egg in relationship to hybrid and age (mean $\pm S E$ )

\begin{tabular}{|c|c|c|c|c|c|c|c|}
\hline \multirow[b]{2}{*}{ Trait } & \multirow{2}{*}{$\begin{array}{c}\text { Age } \\
\text { (weeks) }\end{array}$} & \multicolumn{2}{|c|}{ Hybrid } & \multicolumn{3}{|c|}{ Significance } & \multirow[b]{2}{*}{ SEM } \\
\hline & & $\begin{array}{c}\text { Dominant } \\
\text { D } 102\end{array}$ & $\begin{array}{c}\text { Dominant } \\
\text { D } 229\end{array}$ & Age & Hybrid & Age $\times$ Hybrid & \\
\hline \multirow{3}{*}{ Yolk weight (g) } & 28 & $15.70 \pm 0.16$ & $15.16 \pm 0.23$ & \multirow{3}{*}{0.001} & \multirow{3}{*}{0.001} & \multirow{3}{*}{0.142} & \multirow{3}{*}{0.112} \\
\hline & 35 & $16.94 \pm 0.16$ & $16.65 \pm 0.20$ & & & & \\
\hline & 59 & $20.57 \pm 0.17$ & $19.53 \pm 0.23$ & & & & \\
\hline \multirow{3}{*}{ Yolk index (\%) } & 28 & $56.21^{\mathrm{a}} \pm 0.25$ & $53.72^{\mathrm{b}} \pm 0.35$ & \multirow{3}{*}{0.001} & \multirow{3}{*}{0.001} & \multirow{3}{*}{0.001} & \multirow{3}{*}{0.325} \\
\hline & 35 & $42.38^{c} \pm 0.25$ & $41.22^{\mathrm{d}} \pm 0.31$ & & & & \\
\hline & 59 & $40.52^{\mathrm{d}} \pm 0.26$ & $37.08^{e} \pm 0.35$ & & & & \\
\hline \multirow{3}{*}{ Albumen weight (g) } & 28 & $39.61^{b} \pm 0.32$ & $37.10^{c} \pm 0.46$ & \multirow{3}{*}{0.001} & \multirow{3}{*}{0.001} & \multirow{3}{*}{0.003} & \multirow{3}{*}{0.177} \\
\hline & 35 & $41.47^{\mathrm{a}} \pm 0.32$ & $36.88^{c} \pm 0.40$ & & & & \\
\hline & 59 & $42.38^{\mathrm{a}} \pm 0.34$ & $37.25^{\complement} \pm 0.46$ & & & & \\
\hline \multirow{3}{*}{ Albumen index (\%) } & 28 & $7.18^{a} \pm 0.16$ & $6.06^{c} \pm 0.22$ & \multirow{3}{*}{0.001} & \multirow{3}{*}{0.885} & \multirow{3}{*}{0.001} & \multirow{3}{*}{0.083} \\
\hline & 35 & $6.62^{b} \pm 0.16$ & $7.64^{a} \pm 0.20$ & & & & \\
\hline & 59 & $5.21^{\mathrm{d}} \pm 0.17$ & $5.24^{\mathrm{d}} \pm 0.23$ & & & & \\
\hline \multirow{3}{*}{ Haugh units } & 28 & $76.27^{\mathrm{a}} \pm 0.86$ & $69.62^{\mathrm{b}} \pm 1.24$ & \multirow{3}{*}{0.001} & \multirow{3}{*}{0.104} & \multirow{3}{*}{0.001} & \multirow{3}{*}{0.484} \\
\hline & 35 & $70.74^{b} \pm 0.86$ & $78.74^{\mathrm{a}} \pm 1.09$ & & & & \\
\hline & 59 & $61.73^{c} \pm 0.93$ & $64.58^{c} \pm 1.25$ & & & & \\
\hline
\end{tabular}

Data labelled with same superscript letters in concrete trait do not differ significantly (abcdeP $\leq$ 0.05); SE - Standard Error; Dominant D 102 - brown egg-layers; Dominant D 229 - white egg-layers; SEM - Standard Error of the Mean

There was not found to be any interaction $(\mathrm{P}=0.142)$ between age and hybrid in yolk weight (Tab. II). The heaviest yolk was found in eggs from 59-week-old Dominant Brown D 102 hens (20.57 g), while the lightest yolk was found in eggs from 28-week-old Dominant Leghorn D 229 (15.16 g) and Dominant Brown D 102 hens (15.70 g). The yolk share (Fig. 1) was significantly $(\mathrm{P}=0.011)$ influenced by interaction between age and hybrid. The highest yolk share was found in eggs from 59-week-old 
III: Correlations between egg weight, eggshell weight, eggshell colour and selected egg quality characteristics in relation to hybrid

\begin{tabular}{|c|c|c|c|c|c|c|}
\hline \multirow{3}{*}{ Trait } & \multicolumn{6}{|c|}{ Hybrid/Trait } \\
\hline & D 102 & D 229 & D 102 & D 229 & D 102 & D 229 \\
\hline & \multicolumn{2}{|c|}{ Egg weight } & \multicolumn{2}{|c|}{ Eggshell weight } & \multicolumn{2}{|c|}{ Eggshell colour } \\
\hline Yolk weight & $0.689^{* * *}$ & $0.772^{* * *}$ & $0.305^{* * *}$ & $0.474^{* * *}$ & & \\
\hline Albumen weight & $0.873^{* * *}$ & $0.859^{* * * *}$ & $0.404^{* * *}$ & $0.531^{* * *}$ & & \\
\hline Eggshell weight & $0.538^{* * *}$ & $0.676^{* * *}$ & & & & \\
\hline Yolk share & $0.151^{* *}$ & $0.277^{* * *}$ & & & & \\
\hline Albumen share & $-0.061^{\mathrm{NS}}$ & $-0.206^{* *}$ & & & & \\
\hline Eggshell share & $-0.313^{* * *}$ & $-0.310^{* * *}$ & & & $-0.250^{* * *}$ & $-0.270^{*+*+}$ \\
\hline Eggshell strength & $-0.009^{N S}$ & $-0.211^{* *}$ & $0.398^{* * *}$ & $0.036^{\mathrm{NS}}$ & $-0.115^{*}$ & $-0.197^{* *}$ \\
\hline Eggshell thickness & $0.004^{\mathrm{NS}}$ & $0.038^{\mathrm{NS}}$ & $0.650^{* * *}$ & $0.451^{* * *}$ & $-0.210^{* * *}$ & $-0.103^{\mathrm{NS}}$ \\
\hline
\end{tabular}

Dominant Leghorn D 229 hens (31.19\%) contrary to eggs from this genotype analysed at age of 28 weeks (26.11\%) and eggs from 28 and 35-week-old Dominant Brown D 102 hens (25.87 and 26.31\%). The yolk index (Tab. II) was significantly $(\mathrm{P}=0.001)$ influenced by interaction between age and hybrid. The highest value of the yolk index was found in eggs from 28-week-old Dominant Brown D 102 hens (56.21\%) and the lowest value of the yolk index was found in eggs from 59-week-old Dominant Leghorn D 229 hens (37.08\%).

The albumen weight (Tab. II) was significantly $(P=0.003)$ influenced by interaction between age and hybrid. The heaviest albumen weight was observed in eggs from 35 and 59-week-old Dominant Brown D 102 hens (41.47 and 42.38g) contrary to eggs from Dominant Leghorn D 229 hens (37.10, 36.88 and $37.25 \mathrm{~g})$. The albumen share (Fig. 1) was significantly ( $\mathrm{P}=0.002$ ) influenced by interaction between age and hybrid. The highest albumen share was found in eggs from 28-week-old Dominant Brown D 102 hens (65.07\%), whereas the lowest albumen share was found in eggs from 59-week-old Dominant Leghorn D 229 hens (59.29\%). Albumen index (Tab. II) was significantly $(\mathrm{P}=0.001)$ influenced by interaction between age and hybrid. The highest value of albumen index was found in eggs from 28-week-old Dominant Brown D 102 hens (7.18\%) and 35-week-old Dominant Leghorn D 229 hens (7.64\%) contrary to eggs from 59-week-old Dominant Brown D 102 (5.21\%) and Dominant Leghorn D 229 (5.24\%) hens. Statistically significant $(\mathrm{P}=0.001)$ interaction between age and hybrid was determined in Haugh units. The highest value of Haugh units was found in eggs from 28-week-old Dominant Brown D 102 hens (76.27) and 35-week-old Dominant Leghorn D 229 hens (78.74) contrary to eggs from 59-week-old Dominant Brown D 102 (61.73) and Dominant Leghorn D 229 (64.58) hens.
Correlations between egg weight, eggshell weight and eggshell colour and some selected egg quality traits were determined in relationship to the hybrid of hens (Tab. III). Significant $(\mathrm{P} \leq 0.001, \mathrm{P} \leq 0.01$, $\mathrm{P} \leq 0.05)$ correlations between the most important egg traits were determined with the exception of the correlations between egg weight and albumen share and eggshell strength in eggs from Dominant Brown D 102 hens and between egg weight and eggshell thickness in eggs from both hybrids. Other non-significant correlations were detected between eggshell weight and strength and between eggshell colour and thickness in eggs from Dominant Leghorn D 229 hens. Highly significant $(P \leq 0.001)$ positive correlations were determined between egg weight and yolk, albumen and eggshell weight and between eggshell weight and yolk and albumen weight and eggshell thickness in both hybrids. Significant negative correlations were found between egg weight and eggshell share and between eggshell colour and eggshell share and strength in both hybrids. The higher correlations between egg weight and yolk and eggshell weight, between eggshell weight and yolk and albumen weight and between eggshell colour and eggshell share and eggshell strength were observed in eggs from Dominant Leghorn D 229 hens in comparison with eggs from Dominant Brown D 102.

\section{DISCUSSION}

The results show that hybrid and age had significant effect on the basic traits of egg quality. In addition, interaction between age and hybrid was found to be significant. Number of authors such as Roberts et al. (2013) or Hanusová et al. (2015) confirm the effect of age on egg quality, while Küçükyllmaz et al. (2012) and Samiullah et al. (2017) confirm the effect of genotype. Zita et al. (2009) and Kraus and Zita (2019) even found the significant effect of genotype, age and their interaction on the egg quality. 
Sokołowicz et al. (2018) claim that genotype has statistically significant effect on egg weight, which is in accordance with our findings. Zita et al. (2009) and Ledvinka et al. (2014) describe effect of age as significant and similarly discovered increasing trend of egg weight with the age. Ledvinka et al. (2014) discovered the interaction between age and genotype in egg weight. Küçükyllmaz et al. (2012) found significant effect of genotype on egg shape index. Vice versa, Hanusová et al. (2015) claim that genotype does not have significant effect on egg shape index. Petričević et al. (2017) also state that age significantly influences egg shape index, which regularly decreases with the age. However, the results from Padhi et al. (2013) show the nonsignificant effect of age and irregular trend. Furthermore, Petričević et al. (2017) observed the interaction between age and genotype in egg shape index but did not determine it as significant. However, findings from Zita et al. (2009) or Kraus and Zita (2019) show the opposite.

Unlike our results, Tưmová et al. (2007) discovered significant effect of the genotype on eggshell weight. Padhi et al. (2013) similarly confirm that age significantly influences eggshell weight and that eggshell weight fluctuates with the age. Petričević et al. (2017) agree that the interaction between age and genotype in eggshell weight is significant. Küçükyllmaz et al. (2012) claim that genotype significantly influences eggshell share. Samiullah et al. (2017) discovered the significant effect of age on eggshell share, which regularly decreased with the age. Kraus and Zita (2019) found the interaction between age and genotype in eggshell share. Authors such as Tůmová et al. (2007) or Hanusová et al. (2015) confirm the significant effect of genotype on eggshell thickness. According to Lee et al. (2016) the effect of age on eggshell thickness is statistically significant, which contradicts our results. Furthermore, findings from Lee et al. (2016) show decreasing trend of eggshell thickness with the age. Zita et al. (2009) found the significant interaction between age and genotype in eggshell thickness, whereas Petričević et al. (2017) claim the opposite. Küçükyılmaz et al. (2012) state that genotype influences eggshell strength, while Roberts et al. (2013) found the significant effect of age on eggshell strength, which regularly decreased with the age. The interaction between age and genotype was found to be significant by Zita et al. (2009) but non-significant by Kraus and Zita (2019). Sokołowicz et al. (2018) observed that genotype significantly influences eggshell colour. Samiullah et al. (2017) confirm significant effect of age on this trait and simultaneously confirm increasing trend of eggshell colour with the age. Kraus and Zita (2019) confirmed significant interaction between age and genotype in eggshell colour.

Hanusová et al. (2015) confirm that genotype has significant effect on yolk weight. Padhi et al. (2013) state that yolk weight is significantly influenced by age and that yolk weight regularly increases with the age. In contrast, the findings from Zita et al. (2009) show the significant interaction between age and genotype in yolk weight. Kraus and Zita (2019) claim that genotype, age and their interaction significantly influence yolk share and add that it fluctuates with the age. Tưmová et al. (2007) determined the significant effect of genotype on yolk index. According to Padhi et al. (2013) yolk index is significantly influenced by age and the trend is irregular with the age. Ledvinka et al. (2014) found statistically significant interaction between age and genotype in yolk index.

Various authors such as Zita et al. (2009) or Hanusová et al. (2015) discovered the significant effect of genotype on albumen weight in their studies. Padhi et al. (2013) state that age significantly influences albumen weight, which has at first increasing and then decreasing trend with the age. Furthermore, findings from Zita et al. (2009) confirm the significant interaction between age and genotype in albumen weight. Ledvinka et al. (2014) state that genotype significantly influences albumen share, while Padhi et al. (2013) confirm the significant effect of age. Moreover, results from Padhi et al. (2013) show that albumen share fluctuates with the age. Kraus and Zita (2019) claim that there is the interaction between age and genotype in albumen share. Unlike our results, results from Zita et al. (2018) confirm the significant effect of genotype on albumen index, while the results from Kraus and Zita (2019) show the significant effect of age on this trait. Kraus and Zita (2019) claim that the trend of albumen index is irregular with the age. Ledvinka et al. (2014) state that there is the significant interaction between age and genotype in albumen index. Tưmová et al. (2007) did not find any significant effect of genotype on Haugh units, but Petričević et al. (2017) claim the exact opposite. According to Samiullah et al. (2017), Haugh units are significantly affected by age and constantly decrease with the age. Moreover, Petričević et al. (2017) found the significant interaction between age and genotype.

Large number of authors such as Zita et al. (2009), Mitrovic et al. (2010) or Padhi et al. (2013) calculated correlations among the traits of egg quality. All of the mentioned authors determined correlations primarily between egg weight and other egg quality traits. Furthermore, Zita et al. (2009) calculated correlations for eggshell share and eggshell colour.

All of the differences in the results of this study and other studies may be caused by several factors. The most important factors that affect the results are use of distinct genotypes and housing systems. Obviously, other factors may significantly influence the results such as dissimilar number of animals, samples or measurements. Nevertheless, majority of observed results is in accordance with the findings of previous studies from various authors. 


\section{CONCLUSION}

The significant effect of hybrid was determined in all observed traits, except for the eggshell weight, the albumen index and the Haugh units. The effect of age was found to be significant in all evaluated traits, with the only exception of the eggshell thickness. Interactions between age and hybrid were nonsignificant only in eggshell weight and yolk weight. Highly significant $(\mathrm{P} \leq 0.001)$ positive correlations were calculated between egg weight and yolk, albumen and eggshell weight and between eggshell weight and yolk and albumen weight and eggshell thickness in both hybrids. Significant $(P \leq 0.05)$ negative correlations were determined between egg weight and eggshell share and between eggshell colour and eggshell share and strength in both hybrids. The variability between quality of eggs from brown and white egg-laying hens is reducing thanks to intensive breeding programmes. However, for better understanding of all differences in egg quality traits between brown and white egg-laying hens, further researches focused on the housing system are required. Understanding of the influence of the housing system is important because of the discussions about cage systems prohibition.

\section{Acknowledgements}

The funds for this research come from an „S” grant of the MEYS of the Czech Republic. This study was accomplished with the assistance of the Demonstration and Experimental Center of the Faculty of Agrobiology, Food and Natural Resources. We would like to thank to Mr. Richard Hardy and to Mrs. Anna Chalašová for the help with the English language correction.

\section{REFERENCES}

ANDERSON, K. E. 2013. Comparison of fatty acid, cholesterol, vitamin A and E composition, and trans fats in eggs from brown and white egg strains that were molted or nonmolted. Poultry Science, 92(12): 3259-3265.

ARTHUR, J. A. and O'SULLIVAN, N. 2005. Breeding chickens to meet egg quality needs. International Hatchery Practice, 19(7): 7-9.

AYGUN, A. 2014. The relationship between eggshell colour and egg quality traits in table eggs. Indian Journal of Animal Research, 48(3): 290-294.

CAMPO, J. L., GIL, M. G. and DÁVILA, S. G. 2007. Differences among white-, tinted-, and brown-egg laying hens for incidence of eggs laid on the floor and for oviposition time. Archiv für Geflügelkunde, 71(3): 105-109.

HANUSOVÁ, E., HRNČÁR, C., HANUS, A. et al. 2015. Effect of breed on some traits of egg quality in laying hens. Acta Fytotechnica et Zootechnica, 18(1): 20-24.

HOOGE, D. M. 2007. Bacillus subtilis spores improve brown egg colour. World Poultry, 23(3): 14-15.

KLEJNOVÁ, L. and KOŽELUHOVÁ, H. 2012. XX. International performance test of commercial layers cage system. The final report (2011-2012). Ústrašice, Czech Republic: International Poultry Testing.

KLEJNOVÁ, L. and KOŽELUHOVÁ, H. 2014. XXII. International performance test of commercial layers cage system. The final report (2013-2014). Ústrašice, Czech Republic: International Poultry Testing.

KRAUS, A. and ZITA. L. 2019. The effect of age and genotype on quality of eggs in brown egg-laying hybrids. Acta Universitatis Agriculturae et Silviculturae Mendelianae Brunensis, 67(2): 407-414.

KÜÇÜKYILMAZ, K., BOZKURT, M., HERKEN, E. N. et al. 2012. Effects of rearing systems on performance, egg characteristics and immune response in two layer hen genotype. Asian-Australasian Journal of Animal Sciences, 25(4): 559-568.

LEE, M. H., CHO, E. J., CHOI, E. S. et al. 2016. The effect of hen age on egg quality in commercial layer. Korean Journal of Poultry Science, 43(4): 253-261.

LEDVINKA, Z., ZITA, L. and KLESALOVÁ, L. 2012. Egg quality and some factors influencing it: A review. Scientia Agriculturae Bohemica, 43(1): 46-52.

LEDVINKA, Z., ZITA, L., TYLLER, M. et al. 2014. Effect of genotype, feather growth-rate gene and the age on the egg quality. Bulgarian Journal of Agricultural Science, 20(6): 1466-1471.

MITROVIC, S., PANDUREVIC, T., MILIC, V. et al. 2010. Weight and egg quality correlation relationship on different age laying hens. Journal of Food, Agriculture \& Environment, 8(3, 4): 580-583.

ODABAŞI, A. Z., MILES, R. D., BALABAN, M. O. et al. 2007. Changes in brown eggshell color as the hen ages. Poultry Science, 86(2): 356-363.

PADHI, M. K., CHATTERJEE, R. N., HAUNSHI, S. and RAJKUMAR, U. 2013. Effect of age on egg quality in chicken. Indian Journal of Poultry Science, 48(1): 122-125.

PETRIČEVIĆ, V., ŠKRBIĆ, Z., LUKIĆ, M. et al. 2017. Effect of genotype and age of laying hens on the quality of eggs and egg shells. Scientific Papers Series D Animal Science, 60: 166-170. 
ROBERTS, J. R., CHOUSALKAR, K. and SAMIULLAH S. 2013. Egg quality and age of laying hens: implications for product safety. Animal Production Science, 53(12): 1291-1297.

SAMIULLAH, S., OMAR, A. S., ROBERTS, J. et al. 2017. Effect of production system and flock age on eggshell and egg internal quality measurements. Poultry Science, 96(1): 246-258.

SAMIULLAH, S., ROBERTS, J. R. and CHOUSALKAR, K. 2015. Eggshell color in brown-egg laying hens - a review. Poultry Science, 94(10): 2566-2575.

SAS INSTITUTE INC. 2011. SAS User's Guide. Statistics. Version 9.4 ed. Cary, NC, US: SAS Inst. Inc.

SOKOŁOWICZ, Z., KRAWCZYK, J. and DYKIEL, M. 2018. Effect of alternative housing system and genotype on egg quality characteristics. Emirates Journal of Food and Agriculture, 30(8): 695-703.

TƯMOVÁ, E., ZITA, L., HUBENÝ, M. et al. 2007. The effect of oviposition time and genotype on egg quality characteristics in egg type hens. Czech Journal of Animal Science, 52(1): 26-30.

TYLLER, M. C2015. Dominant CZ. [Online]. Available at: https://dominant-cz.cz/ [Accessed: 2019. April 26]. WINDHORST, H. V., GABKOWSKY, B. and WILKE, A. 2013. Atlas of the Global Egg Industry. London: The International Egg Commission.

ZITA, L., JENÍKOVÁ, M. and HÄRTLOVÁ, H. 2018. Effect of housing system on egg quality and the concentration of cholesterol in egg yolk and blood of hens of native resources of the Czech Republic and Slovakia. The Journal of Applied Poultry Research, 27(3): 380-388.

ZITA, L., TŮMOVÁ, E. and ŠTOLC, L. 2009. Effects of genotype, age and their interaction on egg quality in brown-egg laying hens. Acta Veterinaria Brno, 78(1): 85-91.

Adam Kraus: krausa@af.czu.cz

Lukáš Zita: zita@af.czu.cz

Ondřej Krunt: krunt@af.czu.cz

Zdeněk Volek: volekz@af.czu.cz

Milan Tyller: tyller@dominant-cz.cz

Vojtěch Anderle: VojtaAnderle@seznam.cz 